\title{
Variation in wood
}

\section{physical properties within stems of Guazuma crinita, a timber tree species in the Peruvian Amazon}

\section{Variación de las propiedades físicas en troncos de Guazuma crinita, una especie maderable en el Amazonas Peruano}

\author{
Lady L. Tuisima-Coral',4, Joel E. Odicio-Guevara², John C. Weber ${ }^{3}$, David Lluncor-Mendoza ${ }^{4}$ and Bohdan Lojkal*
}

1 Czech University of Life Sciences Prague. Depart-
ment of Crop Sciences and Agroforestry, Faculty of
Tropical AgriSciences. Prague, Czech Republic.

* Corresponding author. lojka@aftz.czu.cz

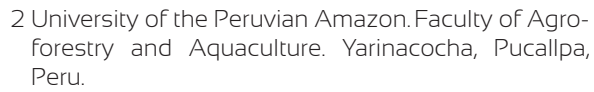

2 University of the Peruvian Amazon. Faculty of Agroforestry and Aquaculture. Yarinacocha, Pucallpa Peru.

3 World Agroforestry Centre. Lima, Peru

4 National University of Ucayali. Faculty of Forest and Environmental Sciences. Pucallpa, Peru

\begin{abstract}
An understanding of wood physical properties and the interrelationships that govern them is required for efficient utilization of timber tree species. Guazuma crinita is a fast-growing timber tree of agroforestry systems in the Peruvian Amazon. The aim of this study was to assess variation in wood physical properties within the G. crinita stem. Wood samples were obtained from the base, middle and top of the stem of 12 randomly selected eight-year-old trees from six provenances in order to determine wood moisture content, density, specific gravity, radial, tangential and volumetric shrinkage and the coefficient of anisotropy. Pearson correlations between physical properties were also determined. The highest basic density was $459 \mathrm{~kg} / \mathrm{m}^{3}$ from Tournavista provenance. Mean basic density and specific gravity were $430 \mathrm{~kg} / \mathrm{m}^{3}$ and 0.45 respectively. There was statistically significant variation $(\mathrm{p} \leq 0.05)$, due to stem level within the trees. The moderate values of density and anisotropy coefficient (1.56) suggest that G. crinita is a stable wood; these are important advantages in terms of costs of the processes of transport and transformation. Given the variation found in the limited tree samples of this study, we recommend further analysis with larger samples from different provenances and planting zones.
\end{abstract}

KEY WORDS: coefficient of anisotropy, specific gravity, shrinkage, wood density.

\section{RESUMEN}

El entendimiento de las propiedades físicas de la madera y de las interrelaciones que las gobiernan es necesario para el uso eficiente de las especies maderables. Guazuma crinita es una especie arbórea de rápido crecimiento en sistemas agroforestales del Amazonas peruano. El objetivo de este estudio fue determinar la variación de las propiedades físicas de la madera en el fuste de árboles G. crinita. Las muestras de madera fueron obtenidas de la base, parte media y parte superior del tronco de 12 árboles de ocho años de edad aleatoriamente seleccionados, de seis lugares de procedencia. Con ellas se determinó: contenido de humedad, densidad, densidad relativa, contracciones radial, tangencial y volumétrica y coeficiente de anisotropía; se determinaron también las correlaciones de Pearson entre las propiedades físicas. La densidad básica mayor fue $459 \mathrm{~kg} / \mathrm{m}^{3}$, de la procedencia de Tournavista. Las densidades básica y relativa promedio fueron $430 \mathrm{~kg} / \mathrm{m}^{3}$ y 0.45 , respectivamente. Se encontró variación estadísticamente significativa $(\mathrm{p} \leq 0.05)$ entre alturas en el fuste. La madera moderadamente densa y el coeficiente de anisotropía (1.56) sugieren que G. Crinita es una madera estable, lo que representa importantes ventajas en términos de costos por transporte y proceso de transformación. Debido a la variación encontrada en las limitadas muestras de árboles de este estudio, se recomienda la realización de más análisis con mayores muestras y de diferentes sitios y plantaciones.

Palabras clave: coeficiente de anisotropía, densidad básica, contracción, densidad de la madera. 


\section{INTRODUCTION}

Guazuma crinita Mart. (Malvaceae) is a native fast-growing pioneer tree species that colonizes the floodplain and disturbed secondary forests in the lowland jungle (below 1,000 m a.s.l.) in the Amazonian basin of Peru, Ecuador, and Brazil (Reynel, Pennington, Pennington, Flores and Daza, 2003). Interest in this species has increased in the past 20 years in the Ucayali region of Peru, as it is adapted to a wide range of soils including agricultural fallows. Guazuma crinita is an important timber tree species used in reforestation programs. The species can be planted in association with other agroforestry tree species and food crops since it has a small crown with thin branches (Rochon, Margolis and Weber, 2007). The wood is soft, durable and easily worked, mainly used for cabinets, walls and boxes and it also has excellent properties for paneling, interior joinery, moldings and matches (Maruyama, Kinoshita, Ishii, Ohba and Saito, 1997; Reynel et al., 2003). In recent years, it has increasingly been used in the plywood industry and in housing construction (Putzel et al., 2013). It is used in carpentry, making small tools and lollipops sticks, toothpicks, handicrafts and sticks matches. The fibrous inner bark is used locally as cordage material (Reynel et al., 2003). The recommended rotation age for these wood products is $6-12$ years, but younger trees are often harvested, and these can be coppiced for successive harvests. The species could contribute significantly to the income of local farmers (Labarta and Weber, 1998; Putzel et al., 2013).

The species can be grown in dense stands of up to 1200 trees/ha in young fallows ( $<3$ years) and up to 500 mature trees/ha $(\geq 25 \mathrm{~cm} \mathrm{dbh})$ after management by smallholders intended for saw timber (Padoch et al., 2008). In natural stands, 400 trees/ha could represent 100 cubic meters of sawnwood production (Current, Rossi, Sabogal and Nalvarte, 2008). Clearings made to prepare land for crops are an ideal habitat for G. crinita, since the species is tolerant of flooding, it is ideal for management in seasonally flooded areas near rivers and streams (Putzel et al., 2013). Trees begin flowering after 2-3 years and can produce millions of seeds that are dispersed by both wind and water at the beginning of the rainy season. These reproductive characteristics probably result in an extensive gene flow, which could produce high levels of genetic variation within populations and relatively low genetic differentiation among populations (Hamrick, Godt and Sherman-Broyles, 1992). Its importance has prompted research focused on identifying the best provenances for growth and improving the management of the species.

Forest plantations with fast-growing tree species have become an important source of wood in the tropics because commercial dimensions can be attained within relatively short rotation periods (Weber and Sotelo-Montes, 2008; Leakey et al., 2012). Genetic variation among trees forms a portion of the genetic diversity of the species and knowledge of this variation is critical for gene conservation programs (White, Adams and Neale, 2007). Most tree improvement programs assess variation in growth, form, adaptability and pest resistance but do not include wood traits (Zobel and Jett, 1995). Evaluation of genetic variation in wood traits is important for applied tree improvement programs that use selection and breeding in order to improve wood production (O'Neill et al., 2001; White et al., 2007). Wood trait variation assessment involves consideration of a number of anatomical, physical and mechanical properties. Certain wood properties are reported to be good indicators of timber properties and uses. G. crinita was chosen as a priority timber tree species by smallholders in the Peruvian Amazon (Toledo and Rincon, 1996; Sotelo-Montes and Weber, 1997); however, little information exists in terms of variation of the wood properties of timber trees species in the Peruvian Amazon (Sotelo-Montes, Vidaurre and Weber, 2003; Sotelo-Montes, Hernandez, Beaulieu and Weber 2006; Sotelo-Montes, Beaulieu and Hernandez 2007; Sotelo-Montes, Hernandez, Beaulieu and Weber, 2008; Weber and Sotelo-Montes, 2008; Weber, Sotelo-Montes, Cornelius and Ugarte, 2011).

Our research represents a preliminary study of variation in the stem physical properties of 12 G. crinita trees from six provenances. This study had three objectives: (i) to determine the variation in moisture content (MC), 
basic density (BD), wood specific gravity (SPG), green density (GD), air-dry density (ADD), oven-dry density (ODD), radial shrinkage, tangential shrinkage, volumetric shrinkage and the tangential to radial shrinkage (T/R) ratio in G. crinita trees; (ii) to evaluate the influence of stem level position (base, middle and top) on these properties; and (iii) to calculate the correlations among physical properties.

\section{MATERIALS AND METHODS}

\section{Study area and wood sample preparation}

The samples were obtained from a seed orchard established in the National Institute for Agricultural Research in Pucallpa CFB km 4, in the Ucayali region of Peru, which is located between $08^{\circ} 22^{\prime} 00^{\prime \prime} \mathrm{S}$ and $74^{\circ} 31^{\prime} 00^{\prime \prime} \mathrm{W}$ at $154 \mathrm{~m}$ a.s.l. The mean annual temperature is $25.2{ }^{\circ} \mathrm{C}$, mean annual rainfall is $2344 \mathrm{~mm}$ and mean relative humidity is $84 \%$. The seed orchard was established in
2006 with second-generation seedlings originating from six populations (provenances: Table 1) within the Aguaytia watershed in the Peruvian Amazon (Figure 1). These seedlings were provided by the World Agroforestry Centre (ICRAF) from a provenance/progeny test described by Rochon et al. (2007). Eight year after establishment, two apparently healthy trees were randomly chosen in each of the six provenances.

In total, the 12 trees were felled at $20 \mathrm{~cm}$ above ground level and cut with a chainsaw into three logs comprising the base, middle and top stem levels. The cut surfaces of the logs were sealed with glaze paint to maintain the moisture content. For determination of the physical properties, small clear-wood specimens were prepared from each log in the carpentry shop at the National University of Ucayali, Pucallpa, Peru. The specimens were sawn and strictly oriented in radial/tangential directions; they were cut from the pith to the outer part of the bole. Due to differences in stem diameter, it was not possible to obtain the same number of

TABLE 1. Six provenances of Guazuma crinita included in the study. The number of evaluated trees was 12 and an average of 12 wood specimens were obtained from each tree.

\begin{tabular}{ccccccc}
\hline \multirow{2}{*}{ Provenances } & \multicolumn{2}{c}{ *UTM Coordinates } & Tree & **Height (m) & **Diameter (cm) \\
\cline { 2 - 4 } & East & North & $N^{*}$ & & \\
\hline Puerto inca (PI) & 503328 & 8958727 & 1 & 10.4 & 13.1 \\
& & & 2 & 13.8 & 14.3 \\
Nueva Requena (NR) & 518637 & 9095053 & 3 & 13.3 & 14.3 \\
& & & 4 & 12.4 & 13.0 \\
Curimana River (CR) & 491115 & 9074726 & 5 & 12.1 & 14.2 \\
& & & 6 & 13.7 & 16.6 \\
San Alejandro (SA) & 486156 & 9021267 & 7 & 10.6 & 13.3 \\
& & & 8 & 12.4 & 14.0 \\
Aguaytia River (AR) & 461057 & 9025361 & 9 & 13.2 & 13.7 \\
& & & 10 & 13.6 & 13.1 \\
Tournavista Road (TR) & 497745 & 9035717 & 11 & 9.8 & 10.7 \\
& & & 12 & 14.5 & 19.2 \\
\hline
\end{tabular}

*Universal Transverse Mercator.

**Height and Diameter at breast height at eight years after establishment. 


\section{Origin of the trees stands}
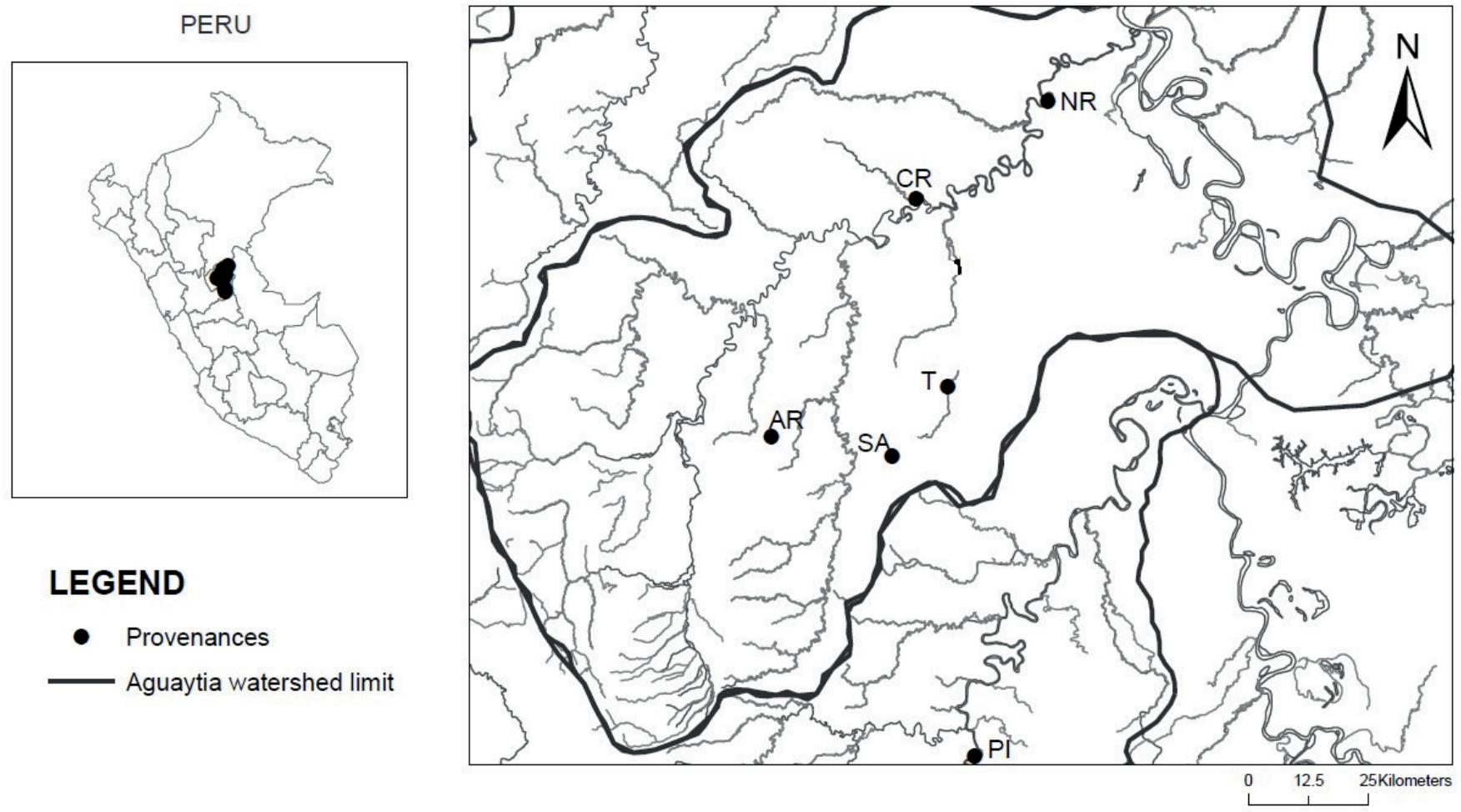

FIgure 1. Provenances included in the study; PI= Puerto Inca, NR= Nueva Requena, $C R=$ Curimana River, $\mathrm{SA}=\mathrm{San} \mathrm{Alejandro,} A \mathrm{R}=$ Aguaytia River and $\mathrm{T}=$ Tournavista.

samples from each log. On average, four specimens each were prepared from the base, middle and top stem levels of each tree (Total number of specimens $=135$ ). The final dimensions of each specimen were $20 \mathrm{~mm}$ radial (R) by 20 $\mathrm{mm}$ tangential (T) by $100 \mathrm{~mm}$ longitudinal (L), and, they were labeled in order to identify the tree and stem level.

\section{Measurement of physical properties}

Laboratory measurements of physical properties were conducted in the laboratory of wood properties at the Amazonian Intercultural University in Ucayali, Pucallpa, Peru. The saturated masses of the 135 wood specimens were determined to the nearest $0.001 \mathrm{~g}$ using a digital balance, and the three principal dimensions were measured to the nearest $0.001 \mathrm{~mm}$ with a digital vernier caliper. The wood specimens were continuously evaluated under room conditions $\left(25^{\circ} \mathrm{C} \pm 2{ }^{\circ} \mathrm{C}\right.$ and relative humidity $65 \% \pm 5 \%$ ) until their moisture content reached approximately $12 \%$ and then they were oven-dried at $103{ }^{\circ} \mathrm{C} \pm 2{ }^{\circ} \mathrm{C}$. The physical properties of the wood measured were moisture content (MC) - [(saturated volume - oven-dry volume)/oven-dry volume] x 100, basic density (BD) - oven-dry weight/saturated volume, green density (GD) - saturated weight/saturated volume, air-dry density (ADD) - air-dry weight/air-dry volume, oven-dry density (ODD) - oven-dry weight/oven-dry volume, and specific gravity (SPG) - oven-dry weight/air-dry volume. Dimensional differences of the samples were used to estimate radial (R), tangential $(\mathrm{T})$ and volumetric shrinkage $(\mathrm{V})$ - [(saturated - oven-dry dimension)/saturated dimension] x 100; and the coefficient of anisotropy (T/R).

\section{Data evaluation}

Descriptive statistics of the wood physical properties were calculated for the six provenances. Analysis of variance 
(ANOVA) was conducted in order to determine whether there were significant differences in physical properties due to the tree stem level (base, middle or top). Differences among tree stem levels were tested using Tukey's test. Pearson correlation coefficients among the physical properties were calculated. All statistical analyses were conducted using SPSS 19 for Windows, and the significance level was $p \leq 0.05$.

\section{RESULTS}

Mean basic density (BD) of all G. crinita trees in the six provenances was $430 \mathrm{~kg} / \mathrm{m}^{3}$ (Table 2). Tournavista Road (TR) provenance had the highest $\mathrm{BD}$, and the Aguaytia River (AR) provenance the lowest BD. Mean specific gravity (SPG) was $0.45 \mathrm{~g} / \mathrm{cm}^{3}$ and showed the same trend as BD for TR and AR provenances. The wood moisture content (MC) also differed between TR and AR provenances, but in this case AR provenance had a higher value than TR provenance. The mean ratio of tangential to radial shrinkage (coefficient of anisotropy T/R) was 1.56. Tangential shrinkage was higher $(4.98 \%)$ than radial shrinkage $(3.38 \%)$. The wood physical properties with greater coefficient of variation were: coefficient of anisotropy (11\%), radial shrinkage $(10 \%)$ and moisture content $(8 \%)$, followed by volumetric shrinkage, wood specific gravity, basic density and oven-dry density with $5 \%$, while air-dry and green density obtained $4 \%$ and $3 \%$ of CV. Comparing the average CV for all densities within provenance, Curimana River (CR) provenance had the highest variation (6\%), followed by AR (4\%), TR $(3.2 \%)$ and the other three provenances $(2 \%)$.

With the exception of MC, all of the physical properties evaluated varied significantly $(p \leq 0.05)$ due to tree stem level, with the highest values found at the stem base level (Table 3). Physical properties in the middle and top levels were statistically similar. The average coefficient of variation for all of the evaluated wood traits was higher for the middle section of the stem (17.6\%) compared to the base $(15.3 \%)$ and top $(16.5 \%)$ sections.

TABLE 2. Physical properties of the six provenances of G. crinita at eight years after establishment. Mean and standard deviation (SD) are given for all wood samples across the provenances and for each provenance individually.

\begin{tabular}{|c|c|c|c|c|c|c|c|c|}
\hline & \multirow{4}{*}{$\begin{array}{l}\text { Physical } \\
\text { properties }\end{array}$} & \multirow{4}{*}{$\begin{array}{c}\text { Across } \\
\text { provenances } \\
\text { Mean } \pm \text { SD }\end{array}$} & \multicolumn{6}{|c|}{ Provenances } \\
\hline & & & Dunto lno & Nueva & Curimana & San & Aguaytia & Tournavista \\
\hline & & & 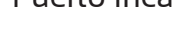 & Requena & River & Alejandro & River & Road \\
\hline & & & Mean \pm SD & Mean \pm SD & Mean \pm SD & Mean \pm SD & Mean \pm SD & Mean \pm SD \\
\hline \multirow{6}{*}{ 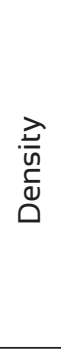 } & SPG & $0.45 \pm 0.02$ & $0.46 \pm 0.01$ & $0.44 \pm 0.01$ & $0.43 \pm 0.03$ & $0.44 \pm 0.02$ & $0.43 \pm 0.03$ & $0.48 \pm 0.01$ \\
\hline & MC (\%) & $70.0 \pm 5.7$ & $66.9 \pm 2.8$ & $75.9 \pm 2.8$ & $68.2 \pm 2.1$ & $68.9 \pm 7.2$ & $76.2 \pm 4.9$ & $64.1 \pm 3.9$ \\
\hline & $\mathrm{BD}\left(\mathrm{kg} / \mathrm{m}^{3}\right)$ & $430 \pm 22$ & $443 \pm 10$ & $424 \pm 3$ & $420 \pm 27$ & $423 \pm 21$ & $411 \pm 23$ & $459 \pm 19$ \\
\hline & Green $\left(\mathrm{kg} / \mathrm{m}^{3}\right)$ & $727 \pm 20$ & $736 \pm 7$ & $744 \pm 6$ & $705 \pm 36$ & $712 \pm 4$ & $722 \pm 20$ & $743 \pm 3$ \\
\hline & Air dry $\left(\mathrm{kg} / \mathrm{m}^{3}\right)$ & $517 \pm 26$ & $535 \pm 1$ & $522 \pm 15$ & $503 \pm 32$ & $505 \pm 21$ & $488 \pm 22$ & $547 \pm 20$ \\
\hline & Oven dry $\left(\mathrm{kg} / \mathrm{m}^{3}\right)$ & $471 \pm 24$ & $488 \pm 13$ & $465 \pm 4$ & $457 \pm 31$ & $464 \pm 2$ & $448 \pm 23$ & $510 \pm 21$ \\
\hline \multirow{4}{*}{ 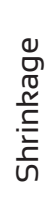 } & $\mathrm{R}(\%)$ & $3.38 \pm 0.35$ & $3.81 \pm 0.18$ & $3.24 \pm 0.13$ & $2.86 \pm 0.06$ & $3.23 \pm 0.07$ & $3.44 \pm 0.36$ & $3.69 \pm 0.13$ \\
\hline & $\mathrm{T}(\%)$ & $4.98 \pm 0.32$ & $4.43 \pm 0.05$ & $5.16 \pm 0.01$ & $4.83 \pm 0.08$ & $5.27 \pm 0.01$ & $4.91 \pm 0.09$ & $5.26 \pm 0.26$ \\
\hline & V (\%) & $8.36 \pm 0.41$ & $8.25 \pm 0.13$ & $8.42 \pm 0.12$ & $7.72 \pm 0.15$ & $8.51 \pm 0.11$ & $8.37 \pm 0.44$ & $8.89 \pm 0.34$ \\
\hline & $T / R$ & $1.56 \pm 0.18$ & $1.25 \pm 0.08$ & $1.62 \pm 0.10$ & $1.72 \pm 0.02$ & $1.69 \pm 0.04$ & $1.60 \pm 0.15$ & $1.49 \pm 0.02$ \\
\hline
\end{tabular}

Note: $\mathrm{SPG}=$ specific gravity; $\mathrm{MC}=$ moisture content; $\mathrm{BD}=$ basic density reported as the ratio of oven dry mass to saturated volume; $\mathrm{R}=$ radial; $T=$ tangential; $\mathrm{V}=$ volumetric; $T / R=$ Ratio tangential/radial. Sample size $=12$ trees. 
TABLE 3. Variation in physical properties of G. crinita based on stem levels. Mean, standard deviation (SD) and coefficient of variance $(\mathrm{CV})$ are presented for 56, 48 and 39 wood samples from the base, middle and top stem levels, respectively.

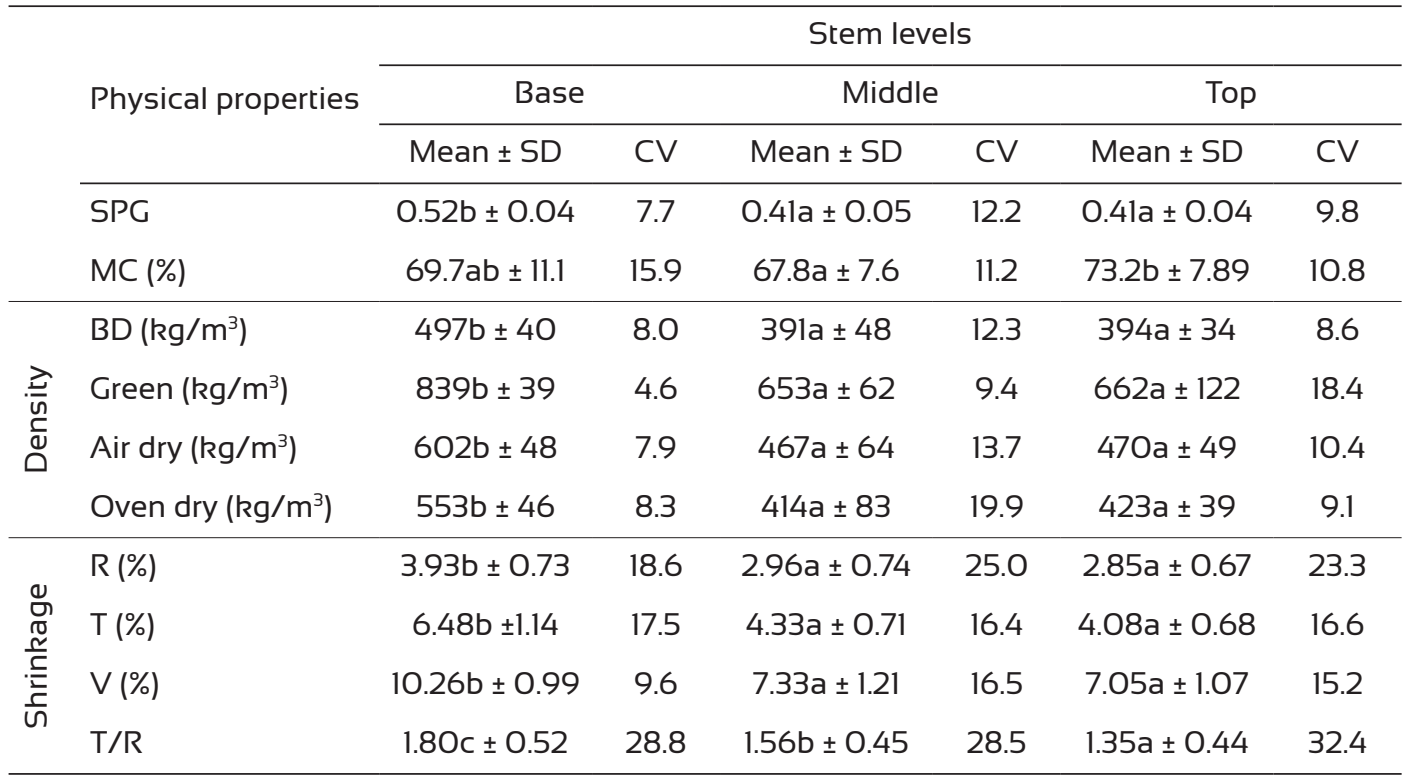

Note: $\mathrm{BD}$ =basic density, SPG = specific gravity; $\mathrm{MC}=$ moisture content; $\mathrm{R}$ = radial; $\mathrm{T}$ = tangential; $\mathrm{V}=$ volumetric. $\mathrm{T} / \mathrm{R}$ = Ratio tangential/radial. Values with a different superscript letter within a row differ significantly based on the Tukey test $(p \leq 0.05)$.

Pearson correlations were positive and highly significant between specific gravity and density at all moisture content levels (i.e., green, air-dry and oven-dry; Table 4). In contrast, MC was negatively correlated with SPG at all densities evaluated.

\section{DISCUSSION}

This study is the first to assess variation in the main physical properties of the wood of G. crinita from the Peruvian Amazon. While only a small number of trees of the six provenances was sampled in this study, there were differences in means among provenances, but we did not statistically analyze the difference. Prior to our study, two tests were conducted to investigate genetic variation in growth, wood density, stem form and mortality among provenances (Rochon et al., 2007; Weber and Sotelo-Montes, 2008; Weber et al., 2011).

The mean basic density of G. crinita wood at eight years of age in our study $\left(430 \mathrm{~kg} / \mathrm{m}^{3}\right)$ was slightly greater than the value reported by Weber and Sotelo-Montes (2008) at 32 months $\left(417 \mathrm{~kg} / \mathrm{m}^{3}\right)$, suggesting that the vari- ation in basic density of this species due to environment and age is not very significant. This is consistent with the fact that wood basic density is under a relatively strong genetic control (Zobel and Jett, 1995). The values published in other reports indicate that G. crinita wood is moderately dense $\left(\sim 410 \mathrm{~kg} / \mathrm{m}^{3}\right.$ to $\sim 600 \mathrm{~kg} / \mathrm{m}^{3}$, Sebille-Martina, 2006). This represents an advantage, compared to denser wood because of the lower transport and transformation costs this implies. Moreover, the wood can be used to build small structures, musical instruments and interior items such as walls and cabinets (Reynel et al., 2003).

Wood from the lower stem of G. crinita at eight years had significantly greater basic density and SPG than wood from the middle and top of the stem (Table 3). Similar results were reported for G. crinita and Calycophyllum spruceanum Benth at younger ages (Weber and Sotelo-Montes, 2005, 2008). Greater density at the bottom of the tree might be an adaptive response to bending stress produced by wind in natural stands (Weber and Sotelo-Montes, 2008). In addition, this reflects a general trend since wood density is usually higher at the base because of 
Table 4. Correlation analyses among wood physical properties of 12 trees from six G. crinite provenances.

\begin{tabular}{cccccccc}
\hline Physical properties & BD & SPG & MC & GD & ADD & ODD & T/R \\
\hline BD & - & & & & & & \\
SPG & $0.937^{* *}$ &. & & & & & \\
MC & $-0.809^{* *}$ & $-0.766^{* *}$ & - & & & & \\
GD & $0.701^{* *}$ & $0.705^{* *}$ & NS & - & & & \\
ADD & $0.934^{* *}$ & $0.873^{* *}$ & $-0.650^{* *}$ & $0.782^{* *}$ & - & & \\
ODD & $0.899^{* *}$ & $0.839^{* *}$ & $-0.659^{* *}$ & $0.690^{* *}$ & $0.899^{* *}$ & - & \\
T/R & NS & NS & NS & NS & NS & NS & - \\
\hline
\end{tabular}

Note: $\mathrm{BD}=$ =basic density; SPG= specific gravity; $\mathrm{MC}=$ moisture content; $\mathrm{CD}=$ green density; $\mathrm{ADD}=$ air dry density; ODD= oven dry density; $T / R=$ Ratio tangential/radial; $\mathrm{NS}=$ not significant; ${ }^{*}$ significant at the 0.05 level; ${ }^{* *}$ significant at the 0.01 level. Sample size $=12$ trees.

the higher compaction by overlapping cells at this level of the bole (Ali, Chirkova, Terziev and Elowson, 2010).

Tangential shrinkage was higher than radial shrinkage $(4.98 \%$ vs. $3.38 \%)$, as has been reported for many tropical tree species (e.g., C. sciadophylla, Laetia procera (Poepp) Eichl, Ocotea guyanensis Aubl, Eschweilera decolorens Sandw, Miconia fragilis Naud, Carapa procera A. D.C, Virola surinamensis (Rolander) Warb, Simarouba amara Aubl, Qualea rosea Aubl (Ruelle, Beauchenea, Thibauta and Thibauta, 2007); C. spreuceanum (Sotelo-Montes et al., 2007).

There was a significant difference in shrinkage among stem levels, with higher values found in the base of the stem (Table 3). The ratio of mean tangential to radial shrinkage (1.56) indicated that the wood of G. crinita is dimensionally stable and homogeneous for primary and secondary transformation, such as narrow boards, ceiling and housing liners (Sebille-Martina, 2006). A similar value was reported by Arostegui (1974).

The physical properties of wood depend upon its moisture content (Pliura et al., 2005; Sebille-Martina, 2006). Correlation between density, specific gravity and moisture content indicated that wood with higher density and specific gravity had a lower moisture content (Table 4). The average wood moisture content (MC) of G. crinita at eight years in this study was $70 \%$. This was lower than the value $(85.6 \%)$ reported by Rivera-Samaniego (2014) for G. crinita trees from a higher altitudinal zone $(660 \mathrm{~m}$ a.s.l.). The MC in the base of the stem was much lower in this study than in that conducted at the higher altitudinal zone $(69.7 \%$ vs $98.5 \%)$. Altitude appears to be an important source of variation in $\mathrm{MC}$ for G. crinita and for other species (Zobel and Jett, 1995). This is supported by some authors who found that wood density of G. crinita is greater in drier than in more humid zones, and humid zones are represented by areas at higher altitude (Rochon et al., 2007; Weber and Sotelo-Montes, 2008). The value found in this study indicated a relatively high amount of free water in the wood structure; the wood would therefore probably have low mechanical resistance and internal stress for drying operations (Ali et al., 2010). Furthermore, Arostegui (1974) reported that the wood of G. crinita performed well during the drying process.

\section{CONCLUSIONS}

We found relatively high variation in wood physical properties among six G. crinita provenances from the Peruvian Amazon. This suggests the high potential for selection of provenances with desirable wood properties for further domestication and breeding.

Guazuma crinita had moderately dense wood at eight years of age and the coefficient of anisotropy indicated that the wood was dimensionally stable. This indicates important advantages in terms of transport and transfor- 
mation costs and the workability of this species. The wood is recommended mainly for manufactured homes, interior furniture, ceilings and boards.

Given that our results suggest variation in wood physical properties within a limited number of tree samples, it is recommended that future studies sample a larger number of tree from each provenance and from different experimental plots in other watersheds in order to accurately identify the provenances that present the most desirable wood properties.

\section{ACKNOWLEDGMENTS}

The authors acknowledge the generous donation of the trees by Ing. Pedro Reyes Inca, at the National Institution for Agricultural Research in Ucayali region, Peru. The study was also supported by the Internal Grant Agency of Czech University of Life Science Prague CIGA (Projects No. 20145005 and No. 20165016).

\section{REFERENCES}

Ali, A. C., Chirkova, J., Terziev, N. and Elowson, T. (2010). Physical properties of two tropical wood species from Mozambique. Wood Material Science and Engineering, 5 (3), 151-161. doi:10.1080/17480272.2010.489649

Arostegui, A. (1974). Estudio tecnológico de maderas del Perú - Características tecnológicas y usos de la madera de 145 especies del país. Lima: Convenio MINAG-UNALM.

Current, D., Rossi, L. M. B., Sabogal, C. and Nalvarte, T. (1998). Comparación de la potencial del manejo de la regeneración natural con asocio agroforestal y plantaciones puras para tres especies: Estudios de caso en Brasil, Perú y Costa Rica CATIE, Turrialba. Recuperado de http://bibliotecaorton.catie.ac.cr.

Hamrick, J. L., Godt, M. J. and Sherman-Broyles, S. L. (1992). Factors influencing levels of genetic diversity in woody plant species. New Forest, 6, 95-124. doi:10.1007/ BF00120641

Labarta, R. A., and Weber, J. C. (1998). Valorización económica de bienes tangibles de cinco especies arbóreas agroforestales en la Cuenca Amazónica Peruana. Revista Forestal Centroamericana, 23, 12-21.
Leakey, R. R. B., Weber, J. C., Page, T., Cornelius, J. P., Akinnifesi, F. K., Roshetko, J. M., Tchoundjeu, Z. and Jamnadass, R. (2012). Tree domesticationin agroforestry: Progress in the second decade (2003-2012). In P. K. R. Nair and D. Garrity (Eds.), Advances in Agroforestry (pp. 145-173). Dordrecht: Springer.

Maruyama, E., Kinoshita, I., Ishii, K., Ohba, K. and Saito, A. (1997). Germplasm conservation of thetropical forest trees, Cedrela odorata L., Guazuma crinita Mart., and Jacaranda mimosaefolia D. Don., by shoot tip encapsulation in calcium-alginate and storage at $12-25^{\circ} \mathrm{C}$. Plant Cell Reports, 16, 393-396.

O’Neill, G., Dawson, I., Sotelo-Montes, C., Guarino, L., Guariguata, M., Current, D. and Weber, J. C. (2001). Strategies for genetic conservation of trees in the Peruvian Amazon. Biodiversity and Conservation, 10, 837-850.

Padoch, C., Brondizio, E., Costa, S., Pinedo-Vasquez, M., Sears, R. and Siqueira, A. (2008). Urban forest and rural cities: multi-sited households, consumption patterns, and forest resources in Amazonia. Ecology and Society, 13 (2), 2. Recuperado de http://www.ecologyandsociety.org/vol13/ iss $2 / \operatorname{art} 2 /$.

Pliura, A., Yu, Q., Zhang, S. Y., Mackay, J., Perinet, P. and Bousquet, J. (2005). Variation in wood density and shrinkage and their relationship to growth of selected young poplar hybrid crosses. Forest Science, 51, 472482.

Putzel, L., Cronkleton, P., Larson, A., Pinedo-Vasquez, M., Salazar, O. and Sears, R. (2013). Peruvian smallholder production and marketing of bolaina (Guazuma crinita), a fast-growing Amazonian timber species: call for a pro-liveliboods policy environment. Recuperado de http://www.cifor.org/library/4257.

Reynel, C., Pennington, R., Pennington, T., Flores, D. and Daza, C. A. (2003). Árboles útiles de la Amazonía Peruana, Manual de identificación ecológica y propagación de las especies. Lima, Perú: Universidad Nacional Agraria La Molina.

Rivera-Samaniego, J. (2014). Variación en el contenido de humedad y contracción a diferentes niveles de fuste de Guazuma crinita en Tingo Maria. Bachelor's Thesis. Agricultural National University of the Selva. 83p. 
Rochon, C., Margolis, H. A. and Weber, J. C. (2007). Genetic variation in growth of Guazuma crinita (Mart.) trees at an early age in the Peruvian Amazon. Forest Ecology and Management, 243, 291-298. doi:10.1016/j. foreco.2007.03.025

Ruellea, J., Beauchenea, J., Thibauta, A. and Thibauta, B. (2007). Comparison of physical and mechanical properties of tension and opposite wood from ten tropical rainforest trees from different species. Annals of Forest Science, 64, 503-510. doi:10.1051/forest:2007027.

Sebille-Martina, A. M. (2006). Guía de procesamiento industrial de muebles de maderas poco conocidos. Lima, Perú: LKS, World Wildlife Fund for Nature.

Sotelo-Montes, C. and Weber, J. C. (1997). Producción de semillas a partir de la domesticación participativa de árboles agroforestales en la Amazonia peruana. Agroforestería en las Américas, 4, 12-17.

Sotelo-Montes, C., Vidaurre, H. and Weber, J. C. (2003). Variation in stem-growth and branch-wood traits among provenances of Calycophyllum spruceanum Benth. from the Peruvian Amazon. New Forests, 26, 1-16.

Sotelo-Montes, C., Hernandez, R. E., Beaulieu, J. and Weber, J. C. (2006). Genetic variation and correlations between growth and wood density of Calycophyllum spruceanum at an early age in the Peruvian Amazon. Silvae Genetica, $55,217-228$.

Sotelo-Montes, C., J. Beaulieu and Hernandez, R. E. (2007). Genetic variation in wood shrinkage, and its correlations with tree growth and wood density of Calycophyllum spruceanum at an early age in the Peruvian Amazon. Canadian Journal of Forest Research, 37, 966-976.

Sotelo-Montes, C., Hernandez, R. E., Beaulieu, J. and Weber, J. C. (2008). Genetic variation in wood color and its correlations with tree growth and wood density of Calycophyllum spruceanum at an early age in the Peruvian Amazon. New Forests, 35- 57-73. doi:10.1007/s11056007-9060-9
Toledo, E. and Rincon, C. (1996). Utilización Industrial de Nuevas Especies Forestales en el Perú. Lima: Cámara Nacional Forestal, Instituto Nacional de Recursos Naturales, Organización Internacional de las Maderas Tropicales. doi:10.1007/978-94-007-4676-3_11

Weber, J. C. and Sotelo-Montes, C. (2005). Variation and correlations among stem growth and wood traits of Calycophyllum spruceanum Benth. from the Peruvian Amazon. Silvae Genetica, 54, 31-41.

Weber, J. C. and Sotelo-Montes, C. (2008). Geographic variation in tree growth and wood density of Guazuma crinita Mart. in the Peruvian Amazon. New Forests, 36, 29-52. doi:10.1007/s11056-007-9080-5

Weber, J. C., Sotelo-Montes, C., Cornelius, J. and Ugarte, J. (2011). Genetic variation in tree growth, stem form and mortality of Guazuma crinita in slower and faster-growing plantations in the Peruvian Amazon. Silvae Genetica, 30, $70-78$.

White, T. L., Adams, W. T. and Neale, D. B. (2007). Forest Genetics. United Kingdom: CABI Publishing.

Zobel, B. J. and Jett, J. B. (1995). Genetics of wood production. Berlin: Springer-Verlag.

Manuscript received on October $8^{\text {th }} 2015$. Accepted on October 26 2016.

This paper must be cited as:

Tuisima-Coral, L. L., Odicio-Guevara, J. E., Weber, J. C., Lluncor-Mendoza, D. and Lojka, B. (2017). Variation in wood physical properties within stems of Guazuma crinita, a timber tree species in the Peruvian Amazon. Madera y Bosques, 23(1), 53-61. doi:10.21829/ myb.2017.2311534 
